ship that would cost $\$ 300-400$ million and be twice the size of the JOIDES Resolution. A decision on whether to build the ship is expected this year.

But according to one NERC official, Britain is unlikely to be keen on restricting its involvement to the planned Japanese effort alone. Japan's interest in earthquakes, he argues, means that the planned Japanese ship could be tied up for years studying plate tectonics in oceanic areas off the Japanese coast. At the same time, the official adds that a European solution - being promoted by France - "is difficult to imagine from a British point of view, at present".

This could change if the European Union (EU) were to back such a programme, he says. But such an outcome seems improbable. The European Commission recently turned down a ECU7-million (US\$9.1 million) proposal for a project, CORSAIRES, involving shallow drilling in sediments. Instead it approved an ECU500,000 feasibility study for the project.

But beyond this, the commission has no interest in deep ocean drilling, according to one official from the Marine Science and Technology programme (MAST). The costs of establishing an ocean drilling programme would require greatly increased funding for the MAST programme, which currently has a budget of ECU228 million.

Moreover, the political will to support deep ocean drilling is lacking both within the top ranks of the commission and among most member states, according to the official.

One possible outcome of the tripartite meeting could be an agreement to continue with ODP until 2003 on the understanding that a new international programme would then be established that would include the Japanese ship. This option is said to be favoured by Germany, although one NERC official says that the prospect of the United Kingdom and France simply withdrawing from ODP "cannot be ruled out".

But such threats are interpreted by some as simply a tactic aimed by the United Kingdom and France at helping to achieve a reduction in their subscriptions to the programme. Scope for such reductions, they point out, might come from the expected enlargement of ODP to include several new minor contributors, such as China, Korea and Brazil.

Others point out that ODP's new Long Range Plan, which is under discussion, goes some way to addressing French and British concerns. Under the new plan, for example, the ship would spend longer periods at single sites than previously.

ODP is putting a brave face on the possibility that Britain and France might withdraw. "The French have rattled their sabre before", says Timothy Francis, the deputy director of ODP, arguing that the high costs of ocean drilling means that no one country or geographical bloc could realistically consider doing it alone.

Declan Butler

\title{
A good year for US biotech, but caution is still advised
}

San Francisco. After the disappointing performance of biotechnology shares in the first half of last year, the US stock market has been cheered by an impressive recovery in the second half, contributing to an overall gain in stock value of 68.4 per cent over the whole year. But there remains a nagging sense inside and outside the industry that the good times may not last.

"If this is sustained, it'll be good for the industry," Costa Sevastopoulos, chairman of Metra Biosystems in Mountain View, California, said in San Francisco last week at the annual healthcare meeting organized by the investment company Hambrecht \& Quist. But he warned that disappointment may be looming: too many areas of research, such as gene therapy and genomics, have overstepped their near-term potential value.

A depressed mood in the industry lifted last year in mid-June, when, after a string of poor results from clinical trials, the Philadelphia-based company Cephalon reported encouraging data from a phase II trial of

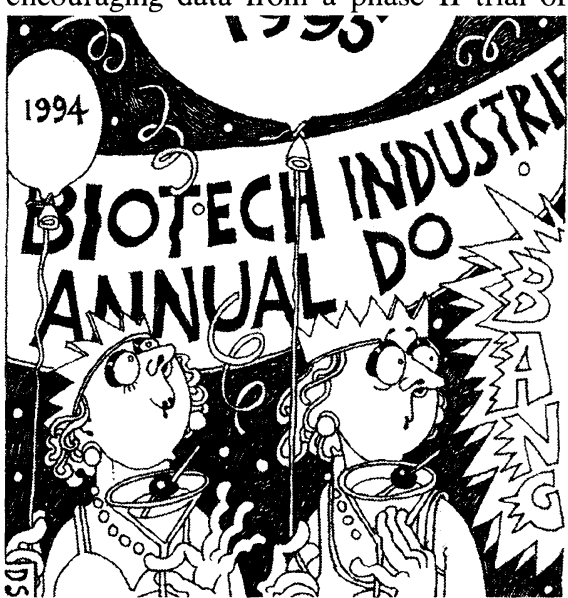

Myotrophin, its treatment for amyotrophic lateral sclerosis (ALS), better known as Lou Gehrig disease.

A rash of positive developments followed. Biochem Pharma of Montreal, began selling 3TC for AIDS; Gilead of Foster City in California filed for approval to market a broad-spectrum antiviral drug; and US Bioscience of Pennsylvania prepared to launch its treatment for advanced ovarian cancer patients.

Industry fortunes subsequently climbed. By the end of 1995, biotechnology companies had raised nearly $\$ 2.2$ billion from the public markets, compared to a little over $\$ 1$ billion in the previous 12 months. New collaborations with pharmaceutical companies increased in value to $\$ 3$ billion from about \$1.9 billion in 1994 .

According to Dennis Purcell, managing director for life sciences at Hambrecht \& Quist, advances in the industry have resulted from the efforts of managers who learned some hard lessons the year earlier. Both the selection of drug targets and the design of clinical trials has become more careful, he said, while companies have cut overhead costs and learned to collaborate.

In all, more than 150 biotechnology products are undergoing phase III clinical trials, according to the investment company. "We're really taking the industry to a new stage," said Purcell. He added that the good news is likely to bring more. Many companies are flush with cash after negotiating link-ups with large drug developers, making them more attractive to investors.

In private, however, many industry leaders have doubts about the solidity of the basis for the market's enthusiasm. They warn that a new crop of young stock analysts and investors from other sectors may lack a sufficiently critical eye. Some of the drugs under development may not bring a significant improvement over existing treatments, they say, or may be too expensive for a costcapped healthcare environment.

A recent merger between two biotechnology companies in south San Francisco, Arris Pharmaceutical Corporation and Khepri Pharmaceuticals, which broadened Arris' technology base and gave Khepri a way of gaining critical mass without going public, may provide a model for mid-size companies that want a hedge against an uncertain future.

Observers of the US biotechnology industry say that up to 40 similar companies could benefit from such relationships with others in their therapeutic area. Diminishing egos, resulting from the recent financial losses, and more financially demanding executive boards, are spurring on the consolidation.

Sevastopoulos sees a new pragmatism in the industry, with seasoned investors and quick-return venture capitalists replacing the early idealists. As a result, start-up companies are finding it harder to attract money, and new ideas are staying longer at the university level, or finding their way into existing companies.

But the second-generation managers, seasoned in the industry and experienced at making deals with major pharmaceutical companies, may contribute to improved sustainability, according to Sevastopoulos. "The arrogance of the past has dissipated," he says.

Sally Lehrman

INRA - Bernard Chevassus. The director of INRA is Bernard Chevassus, and not Roger Cassini, who recently resigned as the French representative to the European Commission's programme of agricultural research, FAIR (see Nature 378, 328; 1995). 